\title{
GREEN INFRASTRUCTURE IN RELATION TO INFORMAL URBAN SETTLEMENTS
}

\author{
Olumuyiwa Bayode ADEGUN \\ School of Architecture and Planning, University of the Witwatersrand, 1 Jans Smuts Avenue, \\ Private Bag 3, Wits 2050, Johannesburg, South Africa \\ E-mail:muyiwaadegun@yahoo.co.uk
}

Received 09 May 2016; accepted 07 February 2017

\begin{abstract}
Green infrastructure plays a critical role in environmentally sustainable urbanization in developing countries. Based on a review of academic outputs, this paper explores green infrastructure in the context of informal urban settlements. It identifies three ways informal settlements are connected to green spaces and natural ecosystems functioning as urban green infrastructure and then shows examples of benefits derived (ecosystem services) by the urban poor from these connections. Undesirable aspects and negative outcomes, regarded as ecosystem disservices, from the connection to natural ecosystems are also pointed out. The potentials of enhancing ecosystem services in terms of improving quality of life and the environment in informal settlements came to the fore. This work contributes to the growing body of knowledge on urban green infrastructure from the perspective of informal settlements in developing countries.
\end{abstract}

Keywords: slums, low-income housing, green spaces, ecosystem services, disservices, developing countries.

\section{Introduction}

Urban sustainability is impossible without considering green infrastructure. Charles Little in the book Greenways for America first introduced the term "green infrastructure", using it to describe networked assemblage of natural landforms and green open spaces that create alternatives to municipal or regional infrastructure (Little 1990). Since then, green infrastructure has been (and still) seen as natural, semi-natural and artificial networks of multifunctional natural ecosystems at different spatial scales (Tzoulas et al. 2007). A network of green spaces (for example, parks) and blue spaces (for example, wetlands), "productive natural landscapes" such as allotment/domestic gardens (Bohn, Viljoen 2011: 150) or a small-scale ecological solution for stormwater management can all be considered as components of green infrastructure.

The notion that environmentally sustainable urbanization cannot be achieved without considering green infrastructure does not seem entrenched in developing countries. As argued in the last two decades, environmental sustainability (with reference to green infrastructure) in low-income informal parts of cities, has not been much of a concern/priority to the state and some non-state actors in many developing countries (Dalgliesh et al. 1997; Magi 1999; Irurah, Boshoff 2003; Groebel 2007; French, Lalande 2013; Shackleton et al. 2014).

This incognizance or poor concern is problematic for the following reasons. Firstly, low-income and informal forms of shelter constitute a notable (and at times growing) proportion of the urban territory and population. ${ }^{1}$ In some developing countries, between 30 and 60 percent of the urban population live in illegal or informal settlements (Mitlin, Satherthwaite 2013). Secondly, these informal areas are usually peopled by the socio-economically disadvantaged, to which environmental disadvantage must be added. They are "victims" of inequalities and vulnerable to the negative impacts of global climate and environmental change (Agbor 2013; Nenweli 2015).

This situation implies there are knowledge gaps regarding bio-physical assets and processes in the

\footnotetext{
1 This paper uses "informal settlements" in broad reference to under-serviced, unregistered, at times illegal, low-income urban environments with flimsy and overcrowded dwellings occupied by the urban poor. These areas might be named differently across the various countries touched on in the paper.
} 
context of informal settlements. It appears that knowledge about the way poor urban dwellers in informal settlements relate with green spaces and natural ecosystems - the benefits derived and detriments experienced - is scanty. Certain examples are available, but they are in bits, scattered in disparate literature not generally articulated in terms of informal housing or urbanism. These gaps preclude appropriate contribution of the necessary understanding to sustainable urbanization (Quilan, McCarthy 1995; Fitchett 2014) and leads to missed opportunities for resilience in the informal context (Schaffler, Swilling 2013; Sachikonye et al. 2016).

This gap informed the research question - how do informal settlement residents relate with green infrastructure, and what benefits/problems emanate from this relationship? In considering the direct or indirect benefits from natural features and ecosystems functioning as green infrastructure (framed as ecosystem services, Fisher et al. 2009), this paper utilizes the Millennium Ecosystem Assessment's (MA) classification of ecosystem services into provisioning, regulating, socio-cultural and supporting services (MA 2005). MA's classification is commonly used and easier to understand, based on the linkage between human welfare and ecological processes (Fisher, Turner 2008). Provisioning services are goods/material outputs from natural ecosystems e.g. food, water while Regulatory services refer to processes that control the environment, for example, micro-climate moderation, air quality control, flood regulation. Socio-cultural services are non-material socio-cultural, spiritual, educational gains from green space and ecosystems. Supporting services underpin the production of other services, with photosynthesis, soil formation, production of atmospheric oxygen as examples. Functions of natural ecosystems that are negative for human beings (regarded as ecosystem services, Lyytimaki, Sipila 2009) were also considered.

\section{Research methods}

This paper is based on a literature review that followed a five-step process (after Green 2005) which include: i) framing a research question; ii) identifying relevant studies; iii) assessing the quality of studies; iv) extracting evidences; $v$ ) analyzing and presenting findings. In identifying relevant studies, a comprehensive search for academic outputs (journal articles, conference proceedings, book chapters) was conducted in Scopus/ Web of Science. Google scholar database was also searched to access outputs such as thesis/dissertation, reports and books which are unavailable in Scopus. Since informal settlements are a third world phenomena and as Onyancha and Ocholla (2009) explain publications by researchers in developing countries that cannot afford the Scopus's subscription fees will be readily available through Google Scholar.

Search algorithms used in the databases combined words such as green infrastructure, green spaces, ecosystem services, ecosystem disservices, informal settlements, slums, ecological, upgrading, sustainability, developing countries. Searching Scopus returned a total of $3000+$ items whose titles were immediately scanned to identify potentially relevant ones. For instance, searching for "green/greening in slums/settlements" led to 1207 items, of which 41 were saved as potentially relevant. Combining "ecological upgrading" with slum/settlement led to 183 items, of which 19 were potentially relevant. "Urban agriculture" in slum/ settlement led to 576 items ( 22 were potential relevant) while "green infrastructure/space" led to 20 items, with 7 designated as potentially relevant. Search using "sustainability and environment" with slum/settlement yielded 1039 items, of which 20 were potentially relevant. Searching Google Scholar also yielded $10000+$ items, of which about 40 thesis/dissertations/books/ reports were selected as potentially relevant.

All the items regarded as potentially relevant were later screened. The criteria - whether the content or part of it conceptualizes or provides example(s) on green spaces and natural ecosystems in relation to low-income informal urban settlements and people living there. The screening reduced the total number. References of the screened publications were checked to identify relevant publications not captured in the searched databases. A total of 68 items were eventually reviewed. These, though at times not conceptually articulated in direct relation to informal housing, reveals how poor urban households draw benefits from natural and semi-natural ecosystems and landforms, vegetation, gardens, waterscapes, agricultural areas and so on. Of the 68 items, 45 are journal articles, 3 conference proceedings, 9 book chapters, 10 thesis/research reports and 1 book. Twenty-six emanated from/ reported research done in South Africa, 8 from India, 4 from Kenya, 2 each from Bangladesh, Brazil, Nigeria, Indonesia, Uganda and Morocco. One each came from Argentina, Burkina Faso, Cameroon, Ethiopia, Ghana, Mexico, Nepal and Rwanda. Ten were either conceptual or generalist and do not fall into any country-specific category.

\section{Connections between informal settlements and green infrastructure}

Generally, there is a connection between informal settlements and green spaces and natural ecosystems functioning as urban green infrastructure. As evident in literature, this connection occurs in three 


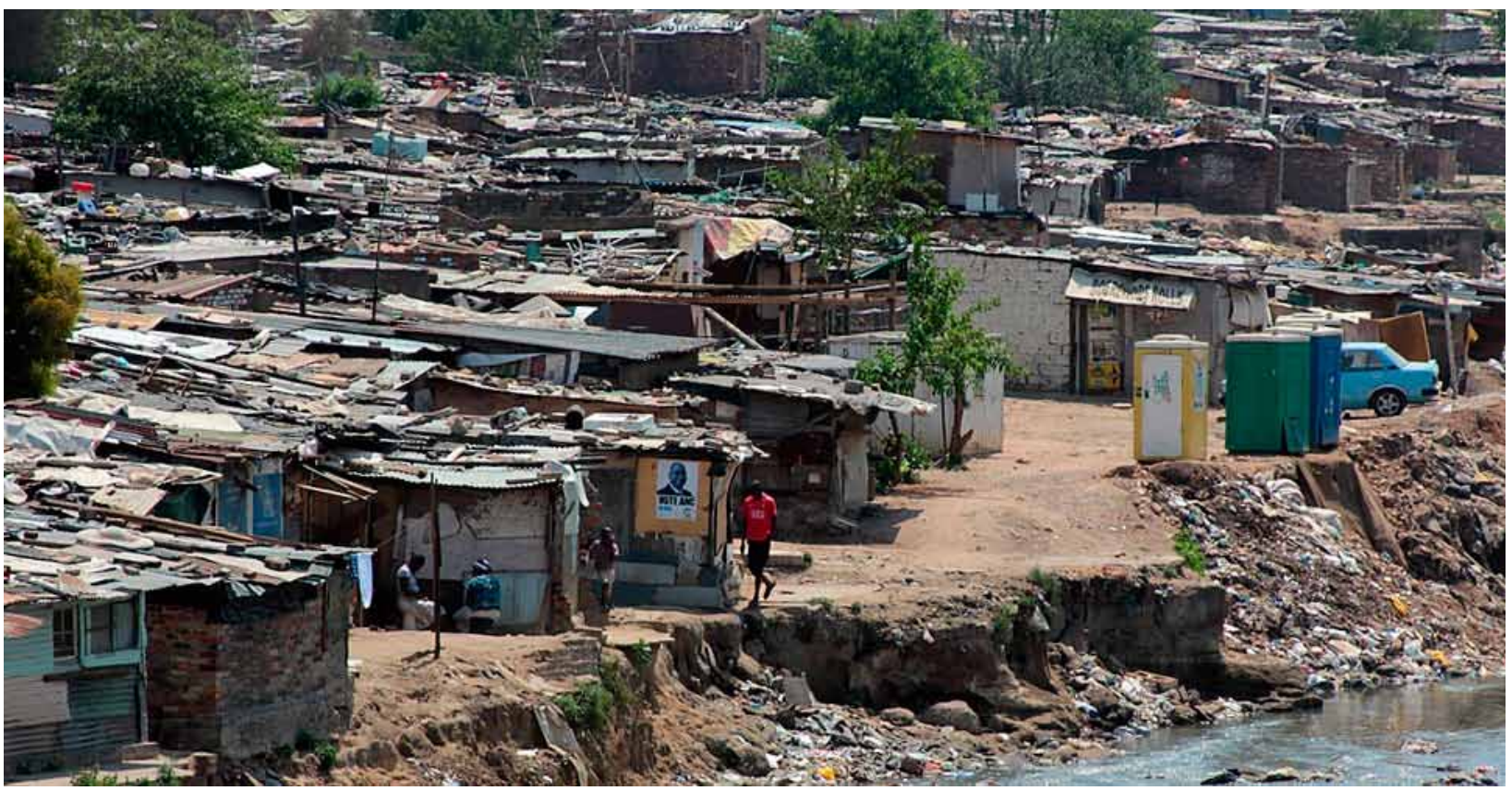

Fig. 1. Alexandra in Johannesburg includes an informal settlement located by the Jukskei River Source: Heather Mason, 2011 (used with permission).

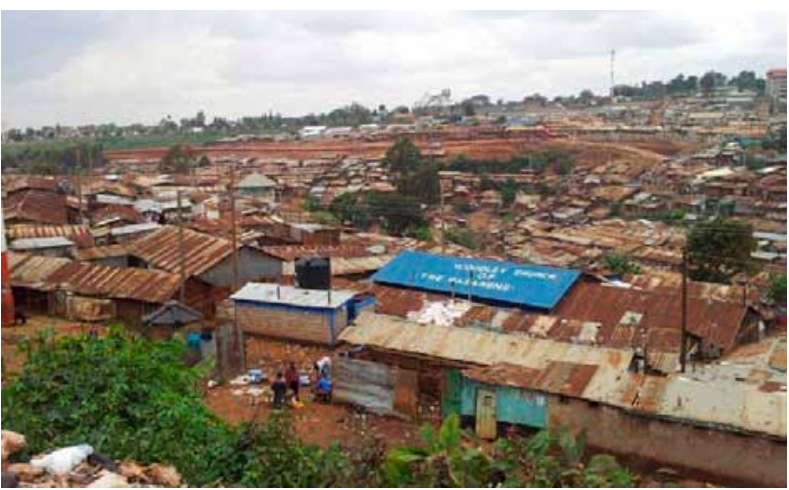

Fig. 2. Kibera settlement is located on a low-lying part of the Nairobi river bank

Source: Author's Photograph, September 2012.

main ways. Location in ecologically-significant, environmentally-sensitive and biodiversity-rich places within cities is one. Agricultural cultivation within low-income urban areas is another, while an ecological approach to infrastructure is the third form of connection.

Across developing countries, informal settlements are generally established through processes that take advantage of unutilized land (Alsayyad 1993; Van Gelder 2010). Such land, often of ecological significance and biodiversity wealth, is unsuitable for residential development because of its location near streams, on low-lying river banks, within wetlands, on steep hillsides or servitudes, buffer strips and other kinds of interstitial space. Through an analysis of urbanisation in developing countries, Seto et al. (2012) and Guneralp

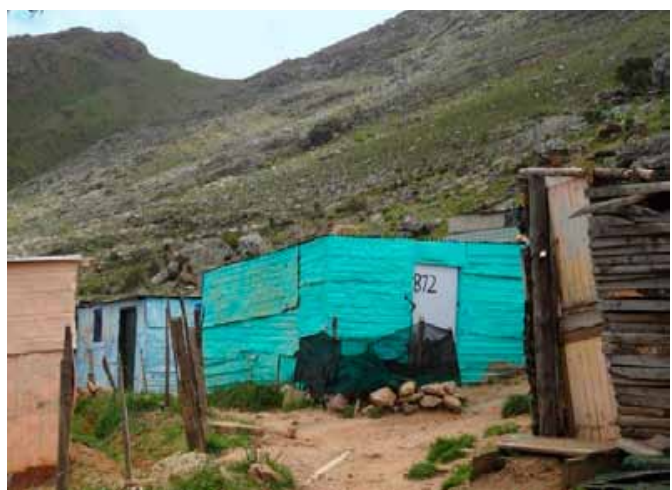

Fig. 3. Langrung informal settlement in Stellenbosch (South Africa) is located on a steep hillside Source: Author's Photograph, October 2013.

et al. (2013) found that urban growth through informal housing development is taking place around and expanding into some of the world's biodiversity-rich areas.

Practical examples of the locational pattern abound. Alexandra settlement in Johannesburg is located the Jukskei River bank (see Fig. 1) while Kibera settlement in Nairobi is located on the Nairobi river bank (see Fig. 2). Langrung informal settlement in Stellenbosch is located on a steep hillside (see Fig. 3). Regarding riparian zones, Vollmer and Gret-Regamey (2013: 1544), observe that due to the presence of informal settlements in low-income Asian countries "population density appears to increase by roughly $10 \%$ within $1 \mathrm{~km}$ of waterways". In Mexico City, between 295 and 300 informal settlements - about $36 \%$ of the city's informal settlements, are located on ecologically 
significant conservation land (Wigle 2014). Part of this informally occupied land make up a unique socio-ecological heritage designated as a World Heritage Site by the United Nations and declared as a Natural Protected Area (NPA) by the Mexican government (ibid.).

It is noteworthy that interventions in and for informal settlements at times tend to perpetuate the locational characteristic pointed to above. This might be an outcome of formal urban planning where certain trade-offs have taken place or otherwise (Hetz, Bruns 2014).

Apart from their location, the second form of connection between informal settlements and green infrastructure takes place through agricultural practices. To a greater or lesser extent, residents of informal settlements undertake various forms of agricultural cultivation, whether through planting in containers or beds in yards, home gardens in stands/plots and communal gardens in open spaces (see Figs 4 and 5) (Redwood 2009; Webb 2011; Hamilton et al. 2014). Irrespective of size and form, these cultivated spaces make up part of green infrastructure.

The third form of connection occurs when infrastructural needs are met through natural or semi-natural systems, at times referred to as ecological infrastructure. This might be at dwelling scale or through catalytic insertions at strategic points. A roof or domestic garden is an example of an ecological infrastructure at the household level. The garden attenuates rainwater, thus controlling runoff's quality and quantity and subsequently reducing the capacity of surface or underground drainage system needed in the settlement. Vertical gardens (for instance in Mtshini Wam settlement, Cape Town - Fig. 4) provides infrastructural functions through micro-climatic controls at the dwelling scale (Henning et al. 2012: 5).

At a wider scale, patches of green open spaces or a wetland can catalyse neighbourhood-wide im-

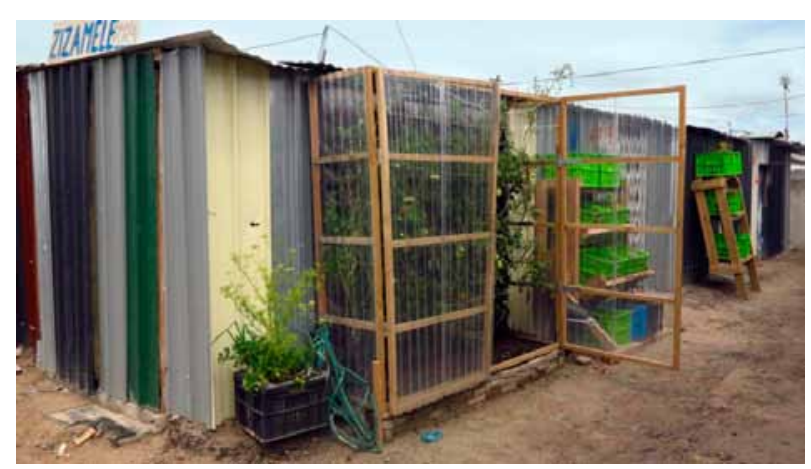

Fig. 4. Vertical gardens by shack walls in re-blocked Mtshini Wam settlement

Source: Stephen Lamb/Design Indaba, 2013 (used with permission). provements. Shaping a wetland as multifunctional for runoff retention, water treatment and vegetable production reduces capacity of the sewage treatment facility needed at the township/municipal level. This wetland-based socio-ecological approach to infrastructure was explored as part of the Tactical Landscape Operations for Informal Settlement Upgrading project in Cantinho do Ceu, Sao Paulo (Werthmann 2011). A positive relationship between ecological development and socio-economic improvement emerged from catalytic projects such as public use of small leftover land, developing wetlands for storm runoff treatment (ibid.).

The connection between informal settlements and urban green infrastructure reveals prospects for climate change adaptation and mitigation in cities (Gill et al. 2007). As shown in the CLUVA project (Lindley et al. 2015) and by Kithiia and Lyth (2011), in the light of resource decline accompanying global climate change, it presents multi-functional, soft engineering alternatives to grey infrastructure in low-income urban areas.

\section{Benefits from green infrastructure in informal settlements}

\section{Provisioning Ecosystem Services}

As a resource fundamental to life, water is a notable product from natural ecosystems. Since municipally-supplied potable water is generally inadequate or absent in informal settlements, the residents often depend on freshwater sources such as streams, wetlands, hand-dug shallow wells or other forms of ground/surface water. For instance, in a Jarkarta settlement where under $30 \%$ of households have access to municipal water provision, over $80 \%$ of households obtain groundwater for washing through wells (Vollmer, Gret-Regamey 2013). Kimani-Murange and Ngindu (2007) reported that $89 \%$ of households depend on groundwater from wells in the Langas settlement in Nairobi while Ochieng et al. (2011) found that $85 \%$ of households depend on wells in three settlements in Ibadan. A similar situation was reported in Assam, India (Phukan 2014). These ground/surface sources are generally of poor quality (Cairncross 1990), but residents use them for cooking, laundry, sanitary purposes and irrigation because they are readily available.

Food, including edible medicinal plants, is another useful product. Academic papers and project outcomes, internationally, affirm the positive role of agricultural cultivation in food supply and food security in low-income informal urban settlements (Davoren 2009; Rau et al. 2011; Dubbeling 2011; Gallaher et al. 2013; 


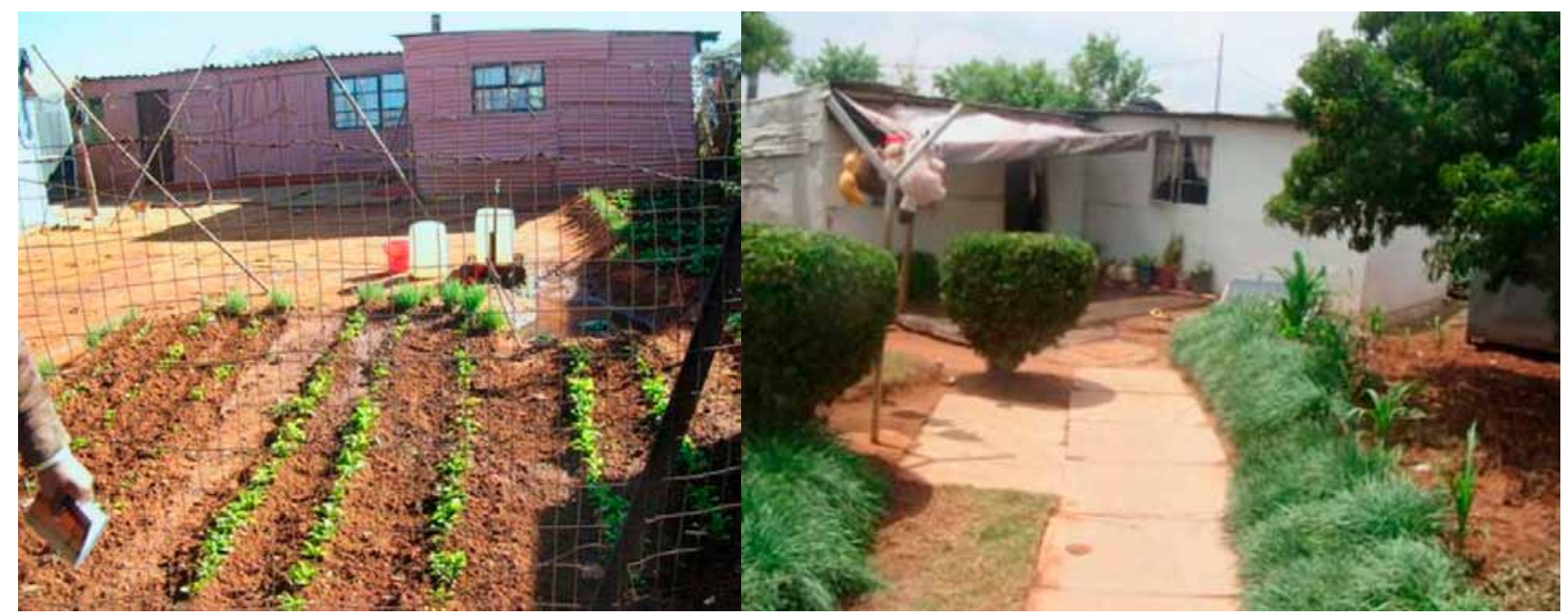

Fig. 5. Home garden in Slovo Park (left) and Elias Motsoaledi (right) informal settlements in Johannesburg Source: Photograph by Marie Huchzermeyer (left), June 2013 and Author (right), December 2012.

UAC 2013; Kornienko 2013), although the informal nature and lack of political recognition in sub-Saharan Africa is an intractable problem (Drechsel, Dongus 2010). Over half of the households in five of Pretoria's informal settlements farmed in home gardens and communal gardens located in public open spaces (van Averbeke 2007). Group farming in open spaces supplied households with about $25 \%$ of annual staple food but home gardeners harvested a meagre 1.7 kilograms of fresh food monthly, which represents $6.7 \%$ of the recommended monthly vegetable intake (ibid.). This means that smaller amounts of food are produced from home gardens, compared to group/communal gardens. In the same vein, informal settlement residents produced fruit and vegetable in Delhi's wetlands (Singh et al. 2013) while those in the Pallikaranai settlement located along the Adyar river in Chennai live on harvested fish (Coelho, Raman 2013).

Timber is another product common in informal settlements. Since the settlements are not formally connected to the electricity grid, timber collected from nearby trees provides fuel for cooking, indoor heating and materials for construction and household furniture. Street trees were sources of timber in low-income Touroua, Cameroon (Epule et al. 2014). Nissing and Von Blottnitz (2007) estimate that 142,000 tonnes of timber, sourced from nearby vegetated areas or industrial waste is used for household thermal purposes annually in Cape Town's informal settlements. In their study of three South African towns, Kaoma and Shackleton (2014) found that at least $43 \%$ of households in informal settlements collected firewood from their own home gardens/plots. These authors did not indicate long-term horizons for replenishment so that timber supply is sustainable.

\section{Regulatory ecosystem services}

People living in informal settlements also benefit from green infrastructure through services that regulate the environment. Three forms of regulatory services are identified. The first relates to micro-climate moderation. An experimental green wall in a Lagos settlement led to around $0.5^{\circ} \mathrm{C}$ decrease in ambient temperature (Oluwafeyikemi, Jullie 2015). In Bangalore, Gopal (2011) observes that most dwellings in informal settlements have plants grown in different kinds of containers. The plants and trees contribute to decrease in local air temperature (by 3 to $5{ }^{\circ} \mathrm{C}$ in summer) and air quality improvement through reduction of pollutants in the neighbourhood (Gopal 2011; Sudhira, Nagendra 2013; Gopal, Nagendra 2014). As a result of their shade, trees in the settlements create cool space for domestic activities (e.g. cooking), livelihood activities (e.g. operation of a mechanic workshop, phone booth) and recreational activities (Gopal 2011; Nagendra et al. 2013).

A further illustration of micro-climatic control comes from the mapping of residential urban morphological types (UMT) in Addis Ababa (Cavan et al. 2014). In what may be particular to Addis Ababa, the study observes that "informal settlements and traditional housing areas have higher proportions and better composition of green structures than other residential areas, and are thus associated with the lowest modelled land surface temperatures" (ibid: 54). The residents benefit from temperature moderation of green spaces in the settlements. Further confirming green spaces' temperature moderation functions, "the use of roof canopies or vegetation to reduce heat exposure were identified as regular practices" in Dakar (Bangladesh) informal settlements (Jabeen et al. 2010: 429). 
As another way of regulating the natural environment, certain natural/semi-natural landforms renders drainage-related functions to informal settlements. As mentioned earlier, a roof garden regulates runoff's quantity and quality. Wetlands and riparian spaces aid flood control and greywater treatment (Adegun 2013; Vollmer et al. 2015; Douglas 2016). Button et al. (2010) experimented with a Sustainable Urban Drainage System (SUDS) that consisted artificial swales and infiltration trenches linked to a wetland in Monwabisi Park informal settlement, Cape Town. Vegetation covering the swales redirects runoff away from unwanted areas. The soakaways incorporate a layer of bio-filtering plants which also redirect excess water to the wetland.

Wind moderation/erosion control is the third form of regulatory ecosystem service. Literature search did not show any contribution made by green infrastructure in this regard. This is being mentioned because some studies show that windstorms are one of the worst climatic events experienced by people living in low-income urban areas (Adelekan 2012; Nenweli 2015).

\section{Socio-cultural ecosystem services}

Benefits related to socio-cultural services are obtained through green spaces that provide aesthetically pleasing environment and opportunities for recreational activities, social interaction, inspirational enrichment or cultural expression in and around informal settlements. For instance, water-bodies or natural areas connected to settlements serve as object of worship and location for religious/cultural ceremonies by residents (Nagendra et al. 2013). Regarding natural ecosystems around the Mandela Park settlement (Cape Town), the residents remarked: "the mountains are beautiful and the trees", "when they do their ritual, the moun- tain becomes the ideal spot" (respondents quoted in Ballantyne, Oelofse 1999: 209). In the same vein, the Macassar informal settlement community's historical connection and cultural ties with the Macassar dune in Western Cape (South Africa) are expressed through recreational practices such as horse riding and fishing by the dune (Graham, Ernstson 2012).

Natural areas also offer opportunities for cognitive development. In La Lagunita settlement, Rosario (Argentina), Dubbeling et al. (2009) observed that green spaces serve as an educationally productive space for children's cognitive development through a demonstration garden and an educational path. As a result of interactions through communal gardening in informal settlements, the gardens contribute to social capital, an outcome that often surpass food benefits from such gardens (Kornienko 2013).

\section{Supporting ecosystem services}

Based on the literature accessed, it is unclear how informal settlements specifically benefit from supporting ecosystem services. However, O'Farrell et al.'s (2012) work stands out as it shows how informally built-up areas (among other land use types) contribute to (but not necessarily benefit from) supporting services. Through an expert opinion's rapid assessment of ecosystem services in Cape Town, O'Farell et al. (2012) shows that natural vegetation remnants in informal areas contribute less to soil retention, critical infiltration and groundwater recharge, yield and quality when compared with formal areas (See Table 1).

Table 2 shows key ecosystem services related to informal urban settlements. It summarises the services (provisioning, regulatory, socio-cultural and supporting) identified so far and includes some references not cited in the narrative.

Table 1. Comparison between certain types of ecosystem services in Cape Town. 0 represents no service while 10 represents maximum potential service

\begin{tabular}{ccc}
\hline & $\begin{array}{c}\text { Formal built-up } \\
\text { residential area }\end{array}$ & $\begin{array}{c}\text { Informal built-up } \\
\text { residential area }\end{array}$ \\
\hline Flood mitigation & 5 & 3 \\
\hline Soil Retention & 9 & 5 \\
\hline Critical Infiltration & 8 & 5 \\
\hline Coastal Zone Protection & 3 & 2 \\
\hline Groundwater Recharge & 6 & 4 \\
\hline Groundwater Yield & 5 & 4 \\
\hline Groundwater Quality & 7 & 5 \\
\hline
\end{tabular}

Source: Extracted from O'Farell et al. (2012). 
Table 2. Summary of key ecosystem services in informal urban areas

\begin{tabular}{|c|c|c|c|}
\hline Service Type & Example & Description & Source(s) \\
\hline \multirow{3}{*}{ Provisioning } & Food & $\begin{array}{l}\text { Food and vegetable production in } \\
\text { wetlands, communal/private open } \\
\text { spaces used as gardens; } \\
\text { Fish production and harvesting in } \\
\text { blue spaces }\end{array}$ & $\begin{array}{c}\text { Van Averberke (2007); Honning (2009); } \\
\text { Rau et al. (2011); Hennings et al. (2012); } \\
\text { Singh et al. (2013); Coelho and Raman } \\
\text { (2013) }\end{array}$ \\
\hline & Water & $\begin{array}{l}\text { Groundwater from shallow wells and } \\
\text { Surface water from streams/rivers - for } \\
\text { domestic use and irrigation }\end{array}$ & $\begin{array}{l}\text { Kimani-Murange and Ngida (2007); } \\
\text { Ochieng et al. (2011); Vollmer and } \\
\text { Gret-Regamey (2013); Phukan (2014) }\end{array}$ \\
\hline & Others & $\begin{array}{l}\text { Timber from trees - for household fuel } \\
\text { and construction; Ttherapeutic flowers, } \\
\text { medicinal items, broom making and } \\
\text { incense stick from plants and trees }\end{array}$ & $\begin{array}{l}\text { Ballantyne and Oelofse (1999); Gopal } \\
\text { (2011); Nagendra et al. (2013); Kaoma and } \\
\text { Shackletion (2014); Epule et al. (2014) }\end{array}$ \\
\hline \multirow{3}{*}{ Regulatory } & $\begin{array}{c}\text { Water } \\
\text { Management }\end{array}$ & $\begin{array}{l}\text { Runoff control management and flood } \\
\text { mitigation; } \\
\text { Greywater treatment }\end{array}$ & $\begin{array}{l}\text { Adegun (2013); Button et al. (2010); } \\
\text { O'Farrell et al. (2012); Douglas (2016) }\end{array}$ \\
\hline & $\begin{array}{l}\text { Moderating } \\
\text { Micro-climate }\end{array}$ & $\begin{array}{c}\text { Trees with canopy provide shade } \\
\text { (decreasing ambient air temperature } \\
\text { by } 3-5^{\circ} \mathrm{C} \text { in summer in Bangalore } \\
\text { urban area/slums) }\end{array}$ & $\begin{array}{c}\text { Jabeen et al. (2010); Gopal (2011); Sudhira } \\
\text { and Negrada (2013); Oluwafiyekemi and } \\
\text { Julie (2015) }\end{array}$ \\
\hline & $\begin{array}{l}\text { Air Quality } \\
\text { Regulation }\end{array}$ & $\begin{array}{l}\text { Cleaning the air through removal of } \\
\text { pollutants such as } \mathrm{SO}_{2} \text { and suspended } \\
\text { particulate matter. }\end{array}$ & Sudhira and Nagendra (2013) \\
\hline \multirow{4}{*}{ Socio-cultural } & Aesthetic & $\begin{array}{c}\text { Pleasant views of nearby natural } \\
\text { environment }\end{array}$ & Ballantyne and Oelofse (1999) \\
\hline & Recreation & $\begin{array}{l}\text { Mountain climbing, tree climbing, } \\
\text { horse riding, fishing, green open } \\
\text { spaces used for other games/sports }\end{array}$ & $\begin{array}{c}\text { Ballantyne and Oelofse (1999); Graham and } \\
\text { Ernstston (2012) }\end{array}$ \\
\hline & $\begin{array}{l}\text { Religious/ } \\
\text { Cultural } \\
\text { fulfilment }\end{array}$ & $\begin{array}{c}\text { Mountainous/lowland areas and } \\
\text { other natural areas used for religious } \\
\text { activities or cultural rites; Wetlands } \\
\text { and other water-bodies as object of } \\
\text { worship }\end{array}$ & $\begin{array}{l}\text { Ballantyne and Oelofse (1999); Gopal (2011); } \\
\text { Nagendra et al. (2013) }\end{array}$ \\
\hline & Educational & $\begin{array}{l}\text { Green Spaces used for demonstrative } \\
\text { teaching and Cognitive development, } \\
\text { especially for children }\end{array}$ & Dubbeling et al. (2009) \\
\hline Supporting & \multicolumn{2}{|c|}{$\begin{array}{l}\text { Soil formation/retention; Critical Infiltration; } \\
\text { Groundwater Recharge }\end{array}$} & O'Farrell et al. (2012) \\
\hline
\end{tabular}

\section{Demand for and supply of ecosystem services types in informal urban areas}

From the aforementioned, it is clear that benefits from green infrastructure (especially provisioning ecosystem services) play a critical role in the lives and livelihood of poor people in informal settlements. According to Sukhdev (2009: 277), these ecosystem services are a kind of wealth - so called "Gross Domestic Product (GDP) of the poor", because of their primary reliance on natural resources. This highlights the need to consider demand (reliance and dependency on) and supply (availability of) ecosystem services in informal settlements.

A number of studies compare demand for provisioning services (material products) with other categories of services. It appears that residents in low-income urban communities place more demand on provisioning services compared with other categories. Of the 720 respondents surveyed by Waters (2013) in three Kampala settlements, $11 \%$ drew benefits related to provisioning services, while only $5.2 \%$ and $3.7 \%$ of the benefits are related to regulatory and cultural services respectively. Although available ecosystem services only make meagre contributions to adaptive capacity in the areas, the study shows that "poorer individuals tend to use provisioning services more while only relatively higher-income individuals value cultural services" (ibid: 109).

Similarly, Shackleton et al.'s (2014) survey compared informal settlements with townships in three South Africa cities. Although both informal settlement and township neighbourhoods are largely low-income 
areas, townships are legally recognised, enjoy better infrastructural services and are wealthier in comparison to informal settlements. The study's comparison on use of tree products shows that informal settlement residents made more use of trees for supply of fruits, timber, fuel and herbal medicine. Township residents were consistently the least likely to collect tree products from within and outside their homes. In total, 80.7\% of respondents in informal settlements collected tree products from their homestead or elsewhere while only $41.3 \%$ did so in the townships (Shackleton et al. 2014). The study did not explore socio-economic factors that might have influenced the lower rate of tree product collection in the formal townships.

In Potchefstroom (South Africa), Lubbe et al. (2010) analysed plant diversity patterns across six urban residential typologies - from peri-urban informal settlements to up-market neighbourhoods. The study found that "a relatively strong negative relationship exists for fruit trees and socio-economic status $\left(R^{2}=0.65\right)$, suggesting that poorer households grow more fruit trees" in order to avoid dependence on market products, gain additional income and improve livelihoods (ibid: 2907). In the same vein, Seburanga et al.'s (2014) observed that non-fruit bearing aesthetic trees were more in high-income areas while fruit-bearing plants were ubiquitously present in the poor non-formal settlements in Kigali.

Seeing that there is higher demand (reliance) on provisioning services in the low-income urban context, is there sufficient and sustainable supply? Here, supply of ecosystem services is understood as the capacity of a particular area (e.g. an informal settlement) to provide or secure those ecosystem goods and services which people rely on, and to do that within a given period (Burkhard et al. 2012). While it is still unclear how the supply of ecosystem services to informal urban areas can be quantified, city-wide supply must be inclusive for the sake of justice. Supply of ecosystem services must respond to inequalities that McConnachie and Shackleton (2010) identifies often characterize the distribution of green spaces in developing countries.

\section{Disadantages from green infrastructure experienced in informal settlements}

Considering negative outcomes and undesirable aspects in the connection between people in informal settlements and natural ecosystems helps to holistically understand the impacts of ecosystems on human well-being. These outcomes, referred to as ecosystem disservices, can emanate from normal functioning of undisturbed ecosystems or result from anthropogenic degradation of ecosystems (Lyytimaki, Sipila 2009).
They are real harm while others are issues based on perceptions (Dunn 2010). I illustrate these with examples from literature.

Problems related to natural ecosystems generally manifest through health threats and other physiological problems. As Douglas (2012) explains, certain aspects of the natural environment have been associated with negative impacts on physical and mental well-being in informal settlements in some situations. Through a survey of informal settlements in Dakar, Gruebner et al. (2012) found that, combined with poor waste disposal and inadequate sanitation, patches of vegetation increased the risk for infectious diseases, especially diarrhea. People living in settlements located close to wetlands often experience invasion of mosquitoes and other insects, because they are bred in these water-logged spaces. Evidences of this come from Kumasi (Campion 2012), Ouagadougou (Baragatti et al. 2009) and Kampala (Isunju et al. 2016). In Ouagadougou, malaria risk correlates with ecological strata (proximity to hydrographic network) and living in irregularly planned settlements (ibid.).

Furthermore, while urban agriculture supports food production and social capital, it can involve health hazards. Irrigation with greywater from polluted drainage channels/streams in informal settlements can contaminate crops. Gallaher et al. (2013) pointed to this as a challenge associated with sack gardening in Kibera settlement in Nairobi.

Disservices from natural ecosystems related to perceptions are exemplified through phobia. Some people dread densely vegetated spaces because they can conceal miscreants and criminal activities (DonaldsonSelby et al. 2007). Fear of being attacked or dwellings being infested by dangerous animals such as snakes, scorpions is another case (Stretha 2010). Problems based on perception can result to those involving real harm. As an illustration, fear of being mugged or raped in an unlit vegetated space can lead to anxiety and depression (psychological problems) as well as hypertension (physiological problems).

These disservices could also occur in formal areas of a city. They, however, stand out in informal settlements because poor spatial configuration, inadequate services and infrastructure, precarious tenure among others make the emanating problems difficult to mitigate. For instance, absence of electricity and street lighting in a settlement makes security measures against night-time criminal activities difficult in densely vegetated areas.

\section{Discussion}

A notable thread emerges from the findings. Benefits (ecosystem services) from green infrastructure have the potential for improvements in the quality of life, 
livelihood and the environment. Aspects of socio-cultural services can support environmental justice and equity (Ferris et al. 2001). "Ecosystem-based adaptation" can create opportunities for local economic development (Roberts et al. 2012: 167). Although seldom harnessed presently, much can be done incrementally to enhance provisioning, regulatory, socio-cultural and supporting ecosystem services in this context. This could be achieved through by encouraging domestic and communal gardening, tree-planting or facilitating co-management of natural ecosystems adjoining settlements.

Harnessing the range of benefits however demands attention that addresses and mitigates the undesirable aspects from green infrastructure. It also demands appropriate local buy-in. For instance, while SUDS presents a promising drainage approach (Jiusto, Kenney 2016), "community involvement in both planning and implementing" is necessary in the low-income, informal setting (Button et al. 2010: 16). As a Rio case shows, the same principle applies to other kinds of greening activities in settlements (Rekow 2016).

High demand on provisioning services, earlier shown, corroborates Cilliers' et al. (2013) view that people from poorer communities directly need useful plants (provisioning ecosystem services) more than people in affluent communities. It can also be linked to the fact that poor people depend directly on the natural resource environment for their livelihood (NadKarni 2000). Furthermore, higher demand highlights the notion of "reliance" and "dependency" in urban settlements in developing countries, contrary to the notion of "enjoyment". Literature from developed countries frames primary benefits from green infrastructure as "enjoyment" (See for example, Andersson 2006; Roy et al.2012; Buchel, Frantsezkaki 2015). Socio-economic conditions in informal urban areas make ecosystem services, especially provisioning, something relied on (fundamental) rather than enjoyed (dispensable). In this situation, reliance relates to survivalism rather than well-being.

\section{Conclusions}

This paper has shown how the urban poor in informal settlements relate with, derive benefits and are negatively affected by connection to different components of green infrastructure. Through the literature reviewed, it is clear that green infrastructure contributes to quality of life, livelihoods and environment - and these contributions can be enhanced. This paper contributes to the growing body of knowledge on green infrastructure from the perspective of informal urban settlements in developing countries.
Future research needs to consider trade-offs that are made in the relationship with natural ecosystems. That is, how a benefit(s) is valued in relation to other benefit(s) or detrimental aspects by those in informal settlements. Also, unpacking the way physical transformations accompanying informal settlement intervention affects the relationship between residents and green infrastructure would be useful. It is necessary to know how ecosystem services and ecosystem disservices are experienced by the residents before or after in situ upgrading or relocation to new housing. This knowledge can contribute to environmentally sustainable intervention in informal settlements across developing countries.

\section{Acknowledgement}

Thanks to Prof. Marie Huchzermeyer and Dr. Brian Boshoff of the School of Architecture and Planning, University of the Witwatersrand, Johannesburg for guidance. The author was supported by grant B8749. R01 from the Carnegie Corporation of New York to the Global Change and Sustainability Research Institute at the University of the Witwatersrand, Johannesburg.

\section{References}

Agbor, K. 2013. Coping with weather in Cape Town: use, adaptation and challenges in an Informal Settlement: Master of Arts Thesis. University of the Western Cape. Cape Town.

Adegun, O. 2013. Sustainable Stormwater management in Johannesburg's informal settlement. Master of Built Environment (Housing) Research Report. University of the Witwatersrand, Johannesburg.

Adelekan, I. O. 2012. Vulnerability to wind hazards in the traditional city of Ibadan, Nigeria, Environment and Urbanization 24(2): 597-617.

https://doi.org/10.1177/0956247812454247

Alsayyad, N. 1993. Squatting and culture: a comparative analysis of informal development in Latin America and the Middle East, Habitat International 17(1): 33-44. https://doi.org/10.1016/0197-3975(93)90044-D

Andersson, E. 2006. Urban landscapes and sustainable cities, Ecology and Society 11(1): 34. https://doi.org/10.5751/ES01639-110134

Ballantyne, R.; Oelofse, C. 1999. Informal settlers' perception of environmental quality: a case study of Mizamoyethu community, South Africa, The Environmentalist 19: 203-215. https://doi.org/10.1023/A:1026446627105

Baragatti, M.; Fournet, F.; Henry, M.-C.; Assi, S.; Ouedraogo, H.; Rogier, C.; Salem, G. 2009. Social and environmental malaria risk factors in urban areas of Ouagadougou, Burkina Faso, Malaria Journal 8: 13. https://doi.org/10.1186/1475-2875-8-13

Bohn, K.; Viljoen, A. 2011. The edible city: envisioning the continuous productive urban landscape (CPUL), Field Journal 4(1): 149-161.

Burkhard, B.; Kroll, F.; Nedkov, S.; Muller, F. 2012. Mapping ecosystem services supply, demand and budgets, Ecological Indicators 21: 17-29. https://doi.org/10.1016/j.ecolind.2011.06.019 
Button, K.; Jeyaraj, E.; Ma, R.; Muniz, E. 2010. Adapting Sustainable urban drainage systems to stormwater management in an informal setting: Bachelor of Science Qualifying Project. Worcester Polytechnic Institute. Cape Town.

Buchel, S.; Frantzeskaki, N. 2015. Citizens' voice: a case study about perceived ecosystem services by urban park users in Rotterdam, the Netherlands, Ecosystem Services 12: 169177. https://doi.org/10.1016/j.ecoser.2014.11.014

Cairncross, S. 1990. Water supply and the urban poor, in S. Cairncross, J. Hardoy, D. Sattherwaithe (Eds). The poor die young: housing and health in the Third World. London: Earthscan, 109-126.

Campion, B. B. 2012. Urban Wetland ecology and flood in Kumasi: Unpublished PhD Thesis. Institut für Geographiean der Universität Bremen.

Cavan, G.; Lindley, S.; Jalayer, F.; Yeshitela, K.; Pauliet, S.; Renner, F.; Gill, S.; Capuano, P.; Nebebe, A.; Woldergerima, T.; Kibassa, D.; Shemdoe, R. 2014. Urban morphological determinants of temperature regulating ecosystem services in two African cities, Ecological Indicators 42: 43-57. https://doi.org/10.1016/j.ecolind.2014.01.025

Cilliers, S.; Cilliers, J.; Lubbe, R.; Siebert, S. 2013. Ecosystem services of urban green spaces in African countries - perspectives and challenges, Urban Ecosystem 16(4): 681-702. https://doi.org/10.1007/s11252-012-0254-3

Coelho, K.; Raman, N. 2013. From the Frying Pan to the flood plain: negotiating land, water and fire in Chennai's development, in A. Rademecher, K. Sivaramakrishnan (Eds.). Ecologies of Urbanism in India: Metropolitan Civility and Sustainability. Kowloon: Hong Kong University Press, 145-168.

Dalgliesh, C.; Bowen, P.; Hill, R. 1997. Environmental sustainability in the delivery of affordable housing in South Africa, Engineering, Construction and Architectural Management 4(1): 23-39. https://doi.org/10.1108/eb021038

Davoren, E. 2009. Plant diversity patterns of a settlement in the North West Province, South Africa: Masters Dissertation. North West University, Potchefstroom.

Donaldson-Selby, G.; Hill, T.; Korrubel, J. 2007. Photoreliastic visualization of urban greening in a low-cost high density housing settlement, Durban, South Africa, Urban Forestry and Greening 6: 3-14. https://doi.org/10.1016/j.ufug.2006.11.001

Douglas, I. 2012. Urban ecology and urban ecosystems: understanding the links to human health and well-being, Current Opinion in Environmental Sustainability 4: 385-392. https://doi.org/10.1016/j.cosust.2012.07.005

Douglas, I. 2016. The challenge of urban poverty for the use of green infrastructure on floodplains and wetlands to reduce flood impacts in intertropical Africa, Landscape and Urban Planning (in press).

https://doi.org/10.1016/j.landurbplan.2016.09.025

Drechsel, P.; Dongus, S. 2010. Dynamics and sustainability of urban agriculture: examples from sub-Saharan Africa, Sustainability Science 5: 69-78. https://doi.org/10.1007/s11625-009-0097-x

Dubbeling, M.; Bracalenti, L.; Lagorio, L. 2009. Participatory design of public spaces for urban agriculture, Rosario, Argentina, Open House International 34(2): 36-49.

Dubbeling, M. 2011. Integrating urban agriculture in the urban landscape, Urban Agriculture Magazine 25: 43-46.

Dunn, R. 2010. Global mapping of ecosystem disservices: the unspoken reality that nature sometimes kills us, Biotropica 42(5): 555-557.

https://doi.org/10.1111/j.1744-7429.2010.00698.x
Epule, E.; Peng, C.; Lepage, L.; Chen, Z. 2014. Enabling conditions for successful greening of public spaces: the case of Touroua, Cameroon based on perceptions, Small-scale forestry 13(2): 143-161.

https://doi.org/10.1007/s11842-013-9246-2

Ferris, J.; Norman, C.; Sempik, J. 2001. People, land and sustainability: community gardens and the social dimension of sustainable development, Social Policy and Administration 35(9): 559-568.

https://doi.org/10.1111/1467-9515.t01-1-00253

Fisher, B.; Turner, R. 2008. Ecosystem services: classification for valuation, Biological Conservation 141: 1167-1169. https://doi.org/10.1016/j.biocon.2008.02.019

Fisher, B.; Turner, R.; Morling, P. 2009. Defining and classifying ecosystem services for decision making, Ecological Economics 68(3): 643-653. https://doi.org/10.1016/j.ecolecon.2008.09.014

Fitchett, A. 2014. Adaptive co-management in the context of informal settlements, Urban Forum 25: 355-374. https://doi.org/10.1007/s12132-013-9215-z

French, M.; Lalande, C. 2013. Green Cities require Green Housing: advancing the economic and environmental sustainability of housing and slum upgrading in cities in developing countries, Local Sustainability 3: 257-284. https://doi.org/10.1007/978-94-007-1969-9_24

Gallaher, C.; Mwaniki, D.; Njenga, M.; Karanja, N.; WinklerPrins, M. 2013. Real or perceived: the environmental health risks of urban sack gardening in Kibera Slums of Nairobi, Kenya, EcoHealth 10: 9-10. https://doi.org/10.1007/s10393-013-0827-5

Gill, S.; Handley, J.; Ennos, A.; Pauleit, S. 2007. Adapting cities for climate change: the role of green infrastructure, Built Environment 33(1): 115-133. https://doi.org/10.2148/benv.33.1.115

Gopal, D. 2011. Flora in slums of Bangalore, India: ecological and socio-cultural perspectives: Master of Science Thesis. Institute of Botany and Landscape Ecology, Ernst Moritz Arndt University of Greifswald, Greifswald.

Gopal, D.; Nagendra, H. 2014.Vegetation in Bangalore's Slums: boosting livelihoods, well-being and social capital, Sustainability 6(5): 2459-2473. https://doi.org/10.3390/su6052459

Graham, M.; Ernstson, H. 2012. Co-management at the fringes: examining stakeholder perspectives at Macassar Dunes, Cape Town, South Africa - at the Intersection of high biodiversity, urban poverty, and inequality, Ecology and Society 17(3): 34. https://doi.org/10.5751/ES-04887-170334

Green, S. 2005. Systematic review and meta-analysis, Singapore Medical Journal 46 (6): 270-274.

Groebel, A. 2007.Sustainable urban development? Low-cost housing challenges in South Africa, Habitat International 31(4): 291-302. https://doi.org/10.1016/j.habitatint.2007.03.001

Gruebner, O.; Khan, M.; Lautenbach, S.; Muller, D.; Kraemer, A.; Lakes, T.; Hostert, P. 2012. Mental health in the slums of Dhaka: a geo-epidemiological study, BMC Public Health 12: 177. https://doi.org/10.1186/1471-2458-12-177

Guneralp, B.; McDonald, R.; Fragkias, M.; Goodness, J.; Marcotullio, P.; Seto, K. 2013. Urbanization forecasts, effects on land use, biodiversity, and ecosystem services, in T. Elmqvist, M. Fragkias, J. Goodness, B. Güneralp, P. Marcotullio, R. McDonald, S. Parnell, S. Schewenius, et al. (Eds.). Urbanization, biodiversity and ecosystem services: 
Challenges and opportunities. Dordrecht: Springer, 437-452. https://doi.org/10.1007/978-94-007-7088-1

Hamilton, A.; Burry, K.; Mok, H.; Baker, S.; Grove, J.; Williamson, V. 2014. Give peas a chance? Urban agriculture in developing countries: a review, Agronomy for Sustainable Development 34(1): 45-73.

https://doi.org/10.1007/s13593-013-0155-8

Hennings, Z.; Mollard, R.; Moreschi, A.; Sawatzki, S.; Young, S. 2012. Supporting re-blocking and community development in MtshiniWam: Interactive Bachelor of Science Qualifying Project. Worcester Polytechnic Institute. Cape Town Centre.

Hetz, K.; Bruns, A. 2014. Urban planning lock-in: implications for the realization of adaptive options towards climate change risks, Water International 39(6): 884-900. https://doi.org/10.1080/02508060.2014.962679

Honning, M. 2009. Improvement of inadequate housing via urban agriculture in Nairobi, Kenya, Open House International 34(2): 71-80.

Irurah, D.; Boshoff, B. 2003. An interpretation of sustainable development and urban sustainability in low-cost housing and settlements in South Africa, in P. Harrison, M. Huchzermeyer, M. Mayekiso (Eds.). Confronting Fragmentation: housing and urban development in a democratic society. Cape town: UCT Press.

Isunju, J. B.; Orach, C.; Kemp, J. 2016. Hazards and vulnerabilities among informal wetland communities in Kampala, Uganda, Environment and Urbanization 28(1): 275-293.

Jabeen, H.; Johnson, V.; Allen, A. 2010. Built-in resilience: learning from grassroots coping strategies for climate variability, Environment and Urbanisation 22(2): 415-431. https://doi.org/10.1177/0956247810379937

Jiusto, S.; Kenney, M. 2016. Hard rain gonna fall: strategies for sustainable urban drainage in informal settlements, Urban Water Journal 13(3): 253-269. https://doi.org/10.1080/1573062X.2014.991329

Kaoma, H.; Shackleton, C. 2014. Collection of urban tree products by households in poorer residential areas of three South African towns, Urban Forestry and Greening 13: 244-252. https://doi.org/10.1016/j.ufug.2014.02.002

Kimani-Murange, E.; Ngindu, A. 2007. Quality of water the slum dwellers use: the case of a Kenyan slum, Journal of Urban Health 84(6): 829-838.

https://doi.org/10.1007/s11524-007-9199-x

Kithiia, J.; Lyth, A. 2011. Urban wildscapes and green spaces in Mombasa and their potential contribution to climate change adaptation and mitigation, Environment and Urbanization 23(1): 251-265. https://doi.org/10.1177/0956247810396054

Kornienko, K. 2013. Engaging informal settlements as landscapes of place: reconceptualising urban communities in the struggle for In Situ upgrading: PhD Thesis. University of the Witwatersrand, Johannesburg.

Lindley, S. J.; Gill, S. E.; Cavan, G.; Yeshitela, K.; Nebebe, A.; Woldegerima, T.; Kibassa, D.; Shemdoe, R.; Renner, F.; Buchta, K.; Abo-El-Wafa, H. 2015. Green infrastructure for climate adaptation in African cities, in Urban Vulnerability and Climate Change in Africa. Springer International Publishing, 107-152.

https://doi.org/10.1007/978-3-319-03982-4_4

Little, C. 1990. Greenways for America. Baltimore: The Johns Hopkins University Press.

Lubbe, C.; Siebert, S.; Cilliers, S. 2010. Political legacy of South Africa affects the plant diversity patterns of urban do- mestic gardens along a socio-economic gradient, Scientific Research and Essays 5(19): 2900-2910.

Lyytimaki, J.; Sipila, M. 2009. Hopping on one leg - the challenge of ecosystem disservices for urban green management, Urban Forestry and Urban Greening 8: 309-315. https://doi.org/10.1016/j.ufug.2009.09.003

Magi, L. 1999. Township recreation patterns and the new order in South Africa, Tourism Geographies 1(3): 293-312. https://doi.org/10.1080/14616689908721323

McConnachie, M. M.; Shackleton, C. M. 2010. Public green space inequality in small towns in South Africa, Habitat International 34: 244-248. https://doi.org/10.1016/j.habitatint.2009.09.009

Millennium Ecosystem Assessment (MA). 2005. Ecosystems and Well-being: Synthesis. Washington, DC: Island Press.

Mitlin, D.; Satterthwaite, D. 2013. Urban poverty in the Global South: scale and nature. London: Routledge.

Nadkarni, M. V. 2000. Poverty, environment, development a many patterned nexus, Economic and Political Weekly 35(14): 1184-1190.

Nagendra, H.; Sudhira, H. S.; Katti, M.; Scheweriius, M. 2013. Sub-regional assessment of India: effects of urbanization on land use, biodiversity and ecosystem services, in T. Elmqvist et al. (Eds.). Urbanization, Biodiversity and Ecosystem Services: Challenges and Opportunities: A Global Assessment. Netherlands: Springer, 65-74. https://doi.org/10.1007/978-94-007-7088-1_6

Nenweli, M. 2015. Informal settlements and climate adaptation in the city of Johannesburg: $\mathrm{PhD}$ Thesis. University of the Witwatersrand, Johannesburg.

Nissing, C.; Von Blottnitz, H. 2007. A material flow analysis of wood and paper in Cape Town: is there potential to redirect flows in formal and informal sectors to foster use as a renewable source?, International Journal of Environment and Sustainable Development 6(2): 147-156. https://doi.org/10.1504/IJESD.2007.014199

Ochieng, G.; Ojo, O.; Ogedengbe, K.; Ndambuki, J. 2011. Open wells, sanitary features, pollutions and water qualities: case study of Ibadan slums, Nigeria, International Journal of the Physical Sciences 6(13): 3062-3073.

O’Farrell, P.; Anderson, P.; Le Maitre, D.; Holmes, P. 2012. Insights and opportunities offered by a rapid ecosystem service assessment in promoting a conservation agenda in an urban biodiversity hotspot, Ecology and Society 17(3): 27. https://doi.org/10.5751/ES-04886-170327

Oluwafeyikemi, A.; Julie, G. 2015. Evaluating the impact of vertical greening systems on thermal comfort in low income residences in Lagos, Nigeria, Procedia Engineering 118: 420-433. https://doi.org/10.1016/j.proeng.2015.08.443

Onyancha, O.; Ocholla, D. 2009. assessing researchers' performance in developing countries: is Google Scholar an alternative?, Mousaion 27(1): 43-64.

Quilan, T.; McCarthy, J. 1995. Is integrated environmental management feasible in the informal settlements of South African cities?, Urban Forum 6(1): 95-111. https://doi.org/10.1007/BF03036695

Phukan, D. K. 2014. Levels of some basic amenities in the slums and their impacts on ecology: a case study of Jorhat City, Assam, International Journal of Science and Research 3(1): 71-74.

Rau, A.; Prystav, G.; Reinhard, M. 2011.Urban agriculture in the megacities of tomorrow - how to improve living 
conditions in informal settlements through urban agriculture - a transdisciplinary German-Moroccan project in Casablanca, in Conference CU EXPO 2011, 10-14 May 2011, Waterloo, Canada.

Redwood, M. 2009. Introduction, in M. Redwood (Eds.). Agriculture in urban planning: Generating livelihoods and food security. International Development Research Centre (IDRC), Ottawa, pp. 1-19.

Rekow, L. 2016. On Unstable ground: issues involved in greening space in the Rocinha Favela of Rio De Janeiro, Journal of Human Security 12(1): 52-73. https://doi.org/10.12924/johs2016.12010052

Roberts, D.; Boon, R.; Diederichs, N.; Douwes, E.; Govender, N.; Mcinnes, A.; Mclean, C.; O’Donoghue, S.; Spires, M. 2012. Exploring ecosystem-based adaptation in Durban, South Africa: "learning-by-doing" at the local government coal face, Environment and Urbanization 24(1): 167-195. https://doi.org/10.1177/0956247811431412

Roy, S.; Jason, B.; Catherine, P. 2012. A systematic quantitative review of urban tree benefits, costs, and assessment methods across cities in different climatic zones, Urban Forestry \& Urban Greening 11(4): 351-363. https://doi.org/10.1016/j.ufug.2012.06.006

Sachikonye, M. T.; Dalu, T.; Gunter, A. 2016. Sustainable livelihood principles and urban greening in informal settlements in practice: a case of Zandspruit informal settlement, South Africa, Development Southern Africa 33(4): 518-531. https://doi.org/10.1080/0376835X.2016.1179101

Schaffler, A.; Swilling, M. 2013. Valuing green infrastructure in an urban environment under pressure - the Johannesburg case, Ecological Economics 86: 246-257. https://doi.org/10.1016/j.ecolecon.2012.05.008

Seburanga, J.; Kaplin, B.; Zhang, Q.; Gatesire, T. 2014. Amenity trees and green space structure in urban settlements of Kigali, Rwanda, Urban Forestry and Urban Greening 13(1): 84-93. https://doi.org/10.1016/j.ufug.2013.08.001

Seto, K.; Güneralp, B.; Hutyra, L. 2012. Global forecasts of urban expansion to 2030 and direct impacts on biodiversity and carbon pools, Proceedings of the National Academy of Sciences 109: 16083-16088.

https://doi.org/10.1073/pnas.1211658109

Shackleton, C.; Hebinck, P.; Kaoma, H.; Chishaleshale, M.; Chinyimba, A.; Shackleton, S.; Gambiza, S.; Gumbo, D. 2014. Low-cost housing developments in South Africa miss the opportunity for household level greening, Land Use Policy 36: 500-509.

https://doi.org/10.1016/j.landusepol.2013.10.002

Singh, S.; Nair, S.; Gupta, A. 2013. Ecosystem Services for disaster risk reduction: a case study of wetland in East Delhi region, India, Global Journal of Human Social Science 13(4): $37-47$.

Stretha, H. K. 2010. Mismatch in technology and culture in wash in rural and informal settlements, in Proceedings of Regional Conference on Appropriate Water Supply, Sanitation, and Hygiene (WASH) Solutions for Informal Settlements and Marginalized Communities, 19-21 May 2010, Kathmandu, Nepal, 335-348.

Sudhira, H.; Nagendra, H. 2013. Local assessment of Bangalore: graying and greening in Bangalore - impacts of urbanization on ecosystems, ecosystem services and biodiversity, in T. Elmqvist (Eds.). Urbanization, biodiversity and ecosystem services: challenges and opportunities: a Global assessment. Netherlands: Springer, pp. 75-91.

https://doi.org/10.1007/978-94-007-7088-1_7

Sukhdev, P. 2009. Costing the Earth, Nature 462: 277. https://doi.org/10.1038/462277a

Tzoulas, K.; Korpela, K.; Venn, S.; Yli-Pelkonen, V.; Kazmierczak, A.; Niemela, J.; James, P. 2007. Promoting ecosystem and human health in urban areas using green infrastructure: a literature review, Landscape and Urban Planning 81: 167-178. https://doi.org/10.1016/j.landurbplan.2007.02.001

Urban Agriculture Casablanca (UAC). 2013. Pilot Project 2: Urban Agriculture + Informal Settlement [online], [cited 26 April 2013]. Available from Internet: www.uac-m.org/ pilot-projects/pilot-project-2/.

Van Averbeke, W. 2007. Urban farming in the informal settlements of Atteridgeville Pretoria, South Africa, WaterSA 33(3): 337-342.

Van Gelder, J. 2010. Tales of deviance and control: on space, rules and law in squatter settlements, Law \& Society Revie 44: 239-68. https://doi.org/10.1111/j.1540-5893.2010.00406.x

Vollmer, D.; Gret-Regamey, A. 2013. Rivers as municipal infrastructure: demand for environmental services in informal settlements along an Indonesian river, Global Environmental Change 23: 1542-1555. https://doi.org/10.1016/j.gloenvcha.2013.10.001

Vollmer, D.; Prescott, M.; Padawangi, R.; Girot, C.; GretRegamey, A. 2015. Understanding the value of urban riparian corridors: considerations in planning for cultural services along an Indonesian river, Landscape and Urban Planning 138: 144-154.

https://doi.org/10.1016/j.landurbplan.2015.02.011

Waters, J. J. 2013. The role of ecosystem services and adaptive capacity in the resilience of poor urban areas: $\mathrm{PhD}$ Thesis. University of East Anglia, Norwich.

Webb, N. 2011. When is enough, enough? Advocacy, evidence and criticism in the field of urban agriculture in South Africa, Development Southern Africa 28(2): 195-208. https://doi.org/10.1080/0376835X.2011.570067

Werthmann, C. 2011. Dirty work: landscape and infrastructure in non-formal cities, in Design with the other $90 \%$ cities. Smithsonian, Cooper-Hewitt National Design Museum. New York, pp. 79-93.

Wigle, J. 2014. The "Graying” of "Green" zones: spatial governance and irregular settlement in Xochimilco, Mexico City, International Journal of Urban and Regional Research 38(2): 573-589. https://doi.org/10.1111/1468-2427.12019

\section{OLUMUYIWA BAYODE ADEGUN}

Earned Architecture Degrees from Federal University of Technology, Akure, Nigeria and PhD from University of the Witwatersrand, Johannesburg, South Africa. He was Visiting Scholar at Canada Centre for Architecture, Montreal. Research interests: informal settlements, housing, green infrastructure, urban renewal. 